\title{
ARTICLE Isolation and Characterization of an Anti-listerial Bacteriocin from Leuconostoc lactis SD501
}

IOPEN ACCESS

\section{Received May 17, 2018 \\ Revised August 8, 2018 \\ Accepted August 9, 2018}

\footnotetext{
*Corresponding author : Dae-Kyung Kang Department of Animal Resources Science, Dankook University, Cheonan 31116, Korea Tel: +82-41-550-3655

E-mail: dkkang@dankook.ac.kr
}

\author{
In-Chan Hwang ${ }^{1}$, Ju Kyoung $\mathrm{Oh}^{1}$, Sang Hoon Kim ${ }^{1}$, \\ Sejong $\mathrm{Oh}^{2}$, and Dae-Kyung Kang ${ }^{1, *}$ \\ ${ }^{1}$ Department of Animal Resource Science, Dankook University, Cheonan 31116, \\ Korea \\ 2Department of Animal Science, Chonnam National University, Gwangju 61186, \\ Korea
}

\begin{abstract}
Although bacteriocins with anti-listerial activity have been isolated from a wide variety of lactic acid bacteria, little is known about those from Leuconostoc lactis, a heterofermentative bacterium that produces diacetyl and exopolysaccharides in dairy foods. In this study, an anti-listerial bacteriocin was isolated from Leuc. lactis SD501 and characterized. It was particularly potent against Listeria monocytogenes and also inhibited Enterococcus faecalis. Anti-listerial activity reached a maximum during the early stationary phase and then decreased gradually. The anti-listerial substance was sensitive to proteinase $\mathrm{K}$ and a-chymotrypsin, confirming its proteinaceous nature. Its activity remained stable at $\mathrm{pH}$ values ranging from 1 to 10 . In addition, it was strongly resistant to high temperatures, retaining its activity even after incubation for 15 min at $121^{\circ} \mathrm{C}$. The apparent molecular mass of the partially purified anti-listerial bacteriocin was approximately $7 \mathrm{kDa}$. The characteristics of the SD501 bacteriocin, including its small molecular size $(<10 \mathrm{kDa})$, strong anti-listerial activity, wide $\mathrm{pH}$ stability and good thermostability, indicate its classification as a Class IIa bacteriocin.
\end{abstract}

Keywords Leuconostoc lactis, bacteriocin, Listeria monocytogenes

\section{Introduction}

For decades, Listeria monocytogenes has been one of the most studied foodborne pathogens, as it causes the severe human illness listeriosis (Low and Donachie, 1997; Schuppler and Loessner, 2010). This microorganism has been repeatedly isolated from both food and the environment, and it contaminates a wide variety of dairy products (Koch et al., 2010; Latorre et al., 2010; Massa et al., 1990; Pintado et al., 2005). It is also frequently present in the guts of cattle, poultry and pigs and can be transferred to ready-to-eat foods or raw meat products (Meyer-Broseta et al., 2003; Pak et al., 2002; Ryser et al., 1996). This bacterium can grow at low temperatures and is relatively tolerant of salt and low pH, rendering its control in foods difficult (Halimi et al., 2010).

(C) Korean Society for Food Science of Animal Resources. This is an open access article distributed under the terms of the Creative Commons Attribution Non-Commercial License (http://creativecommons.org/licences/by-nc/3.0) which permits unrestricted non-commercial use, distribution, and reproduction in any medium, provided the original work is properly cited. 
To date, numerous studies have investigated the control of L. monocytogenes contamination in foods through use of antimicrobials either in formulations or external applications as dips or sprays (Barmpalia et al., 2005; Byelashov et al., 2008; Kim et al., 2015; Lee et al., 2017; Yoon et al., 2009). One promising option for the control of L. monocytogenes is application of lactic acid bacteria (LAB) or their products bacteriocins, which are safe to consume and are also inhibitors of pathogens. Bacteriocins are proteinaceous antimicrobial compounds, and most bacteriocins studied are from the LAB strains that are commonly associated with food, especially fermented dairy and meat products (Halimi et al., 2010; Lecompte et al., 2008; Mathur et al., 2017). Thus, bacteriocins or bacteriocin-producing LAB with anti-listerial activity have been employed to inhibit L. monocytogenes in foods. Marques et al. (2017) reported that film containing a bacteriocin-like substance from Lactobacillus curvatus $\mathrm{P} 99$ effectively controlled L. monocytogenes in sliced cheese. In addition, the combination of a cellbound bacteriocin produced by Lb. curvatus CWBI-B28 with savory essential oils or oregano effectively reduced the number of viable L. monocytogenes in pork meat (Ghalfi et al., 2006).

Although bacteriocins with anti-listerial activity have been isolated from a wide variety of LAB species, including Lactobacillus spp. (Han et al., 2007; Larsen et al., 1993; Xiraphi et al., 2006), Enterococcus spp. (Feng et al., 2009; Seo et al., 2014), Streptococcus spp. (Heng et al., 2007), Leuconostoc spp. (Felix et al., 1994) and Weissella spp. (Papagianni and Papamichae, 2011), little information is available on those from Leuconostoc lactis, a major heterofermentative bacterium that produces diacetyl and exopolysaccharides in dairy foods (Saravanan and Shetty, 2016). In this study, we isolated and characterized a bacteriocin from Leuc. lactis SD501 with strong inhibitory activity against L. monocytogenes.

\section{Materials and Methods}

\section{Bacterial strains, media and growth conditions}

Strains isolated from kimchi were grown in MRS broth (BD Biosciences) at $37^{\circ} \mathrm{C}$. L. monocytogenes ATCC 19114 was grown in tryptic soy broth (BD Biosciences) at $25^{\circ} \mathrm{C}$. Other indicator strains were grown in the media listed in Table 1.

\section{Identification of the isolate}

Genomic DNA from the bacterial strains was extracted and purified. Then, 16S rDNA was amplified via polymerase chain reaction (PCR) using the PCR Thermal Cycler Dice ${ }^{\circledR}$ Gradient (TaKaRa, Japan). The universal primers used for PCR amplification were 5'-AGAGTTTGATCCTGGCTCAG-3' (27F) and 5'-TACGGTTACCTTGTTACGACTT-3' (1492R) (Pavlova et al., 2002). Amplified 16S rDNA fragments from strain SD501 were visualized by $1 \%$ agarose gel electrophoresis. Then, the PCR products were purified using a commercial PCR cleanup kit for the purification of sequencing fragments (MACHEREYNAGEL GmbH, Germany). The sequencing of the 16S rDNA fragment was performed by Cosmogenetech Co., Ltd. (Korea). A homology search was carried out using the NCBI BLAST search program (http://blast.ncbi.nlm.nih.gov/Blast.cgi).

\section{Antimicrobial activity by agar well diffusion assay}

LAB strains were isolated from kimchi and screened for their antagonistic activity against $L$. monocytogenes via the agar well diffusion assay (Lim et al., 2016). Briefly, isolates were grown in MRS broth at $37^{\circ} \mathrm{C}$ for $24 \mathrm{~h}$, and then cells were removed by centrifugation $\left(8,000 \times \mathrm{g}\right.$ for $10 \mathrm{~min}$ at $\left.4^{\circ} \mathrm{C}\right)$. The cell-free supernatant was adjusted to $\mathrm{pH} 7.0$ using $3 \mathrm{~N} \mathrm{NaOH}$ and sterilized using a disposable syringe filter $(0.45 \mu \mathrm{m}$ pore size; BioFACT, Korea) prior to the antimicrobial activity assay. Indicator strains $(0.1 \%, \mathrm{v} / \mathrm{v})$ were added to soft agar medium $(0.75 \%$ agar $)$ and mixed well. The agar plates were allowed to solidify, and the 
Table 1. Indicator strains, growth media and sensitivities to Leuconostoc lactis SD501 cell-free supernatant

\begin{tabular}{|c|c|c|c|}
\hline Indicator organism & Media & Inhibition zone* & Temperature $\left({ }^{\circ} \mathrm{C}\right)$ \\
\hline \multicolumn{4}{|l|}{ Gram-positive } \\
\hline Listeria monocytogenes ATCC 19114 & TSB & +++ & \multirow[t]{3}{*}{25} \\
\hline Enterococcus faecalis (VRE) CCARM 0011 & NB & + & \\
\hline Bacillus licheniformis KCCM 12145 & NB & - & \\
\hline Bacillus cereus KCTC 1661 & LB & - & \multirow{4}{*}{37} \\
\hline Streptococcus agalactiae ATCC 13813 & TSB & - & \\
\hline Staphylococcus aureus KFRI 00188 & NB & - & \\
\hline Staphylococcus subsp. aureus (MRSA) KCCM 40510 & NB & - & \\
\hline \multicolumn{4}{|l|}{ Gram-negative } \\
\hline Escherichia coli $\mathrm{K} 88$ & LB & - & \multirow{5}{*}{37} \\
\hline Salmonella gallinarum KVCC-BA0700722 & NB & - & \\
\hline Pseudomonas aeruginosa KCCM 11266 & NB & - & \\
\hline Shigella flexneri КCCM 40414 & NB & - & \\
\hline Klebsiella pneumoniae КССМ 11418 & NB & - & \\
\hline \multicolumn{4}{|l|}{ Fungi } \\
\hline Candida albicans KCTC 7122 & PDA & - & 30 \\
\hline
\end{tabular}

* Activity is expressed based on the diameter of the inhibition zone around the well. Degrees of inhibition around the well: -, no inhibition; +, up to $5 \mathrm{~mm}$; +++, up to $20 \mathrm{~mm}$.

ATCC, American Type Culture Collection; CCARM, Culture Collection of Antimicrobial Resistant Microbes; KCCM, Korean Culture Center of Microorganisms; KCTC, Korean Collection for Type Culture; KFRI, Kerala Forest Research Institute; KVCC, Korea Veterinary Culture Collection; TSB, tryptic soy broth; NB, nutrient broth; LB, Luria-Bertani; PDA, potato dextrose agar.

wells were punched into the agar plates using a sterile glass cylinder. These wells were filled with $200 \mu \mathrm{L}$ cell-free supernatant from the isolates, and then the plate was incubated at the appropriate temperature for the indicator strains. Antimicrobial activity was detected based on the presence of a clear zone around the wells. All bacteria tested are shown in Table 1.

\section{Production of an anti-listerial substance during the growth of SD501}

Bacteriocin production during bacterial growth was monitored in $250 \mathrm{~mL}$ Erlenmeyer flasks inoculated at 1\% (v/v) with an overnight culture of strain SD501 incubated at $37^{\circ} \mathrm{C}$. Samples were collected at 3- to 12 -h intervals during a $72 \mathrm{~h}$ incubation period, and cell growth and antimicrobial activity were measured. Cell growth was represented by optical density (OD) measurements at $600 \mathrm{~nm}$ using a spectrophotometer (Shimadzu, Japan), and the antimicrobial activity of the cell-free supernatant after neutralization was expressed as arbitrary activity units (AU) per mL. One AU was defined as the reciprocal of the highest dilution that showed inhibition of growth of L. monocytogenes ATCC 19114, the indicator strain, in the agar well diffusion method described above. All experiments were performed in triplicate. The titer was measured using the formula $\mathrm{AU} / \mathrm{mL}=\left[2^{\mathrm{x}}\right] \times[1,000 / \mathrm{V}(\mu \mathrm{L})]$, where $\mathrm{X}$ is the number of the final dilution showing inhibition, and $\mathrm{V}$ is the volume of bioactive liquid (Chumchalova et al., 1995).

\section{Purification of the anti-listerial substance}

Anti-listerial bacteriocin purification was carried out via a three-step procedure using the supernatant of a $4 \mathrm{~L}$ culture of 
Leuc. lactis SD501 grown to the early stationary phase in MRS broth at $37^{\circ} \mathrm{C}$. First, ammonium sulfate was gradually added to the cell-free supernatant (70\% saturation) of Leuc. lactis SD501, which was stirred for $12 \mathrm{~h}$ at $4{ }^{\circ} \mathrm{C}$ and then centrifuged $\left(8,000 \times \mathrm{g}\right.$ for $30 \mathrm{~min}$ at $\left.4^{\circ} \mathrm{C}\right)$. The pellet was resuspended in $50 \mathrm{mM}$ Tris- $\mathrm{Cl}$ buffer $(\mathrm{pH} 7.0)$ and dialyzed using dialysis membrane (Pre-wetted RC tubing [MWCO: $1 \mathrm{kD}$ ], Spectra/Por ${ }^{\circledR}$, USA). The dialyzed product was mixed with Amberlite XAD-16N resin (Sigma-Aldrich, USA) that had been previously activated and equilibrated with $50 \%(\mathrm{v} / \mathrm{v})$ isopropanol, and the substance was incubated for $12 \mathrm{~h}$ at $4{ }^{\circ} \mathrm{C}$ to allow to adsorb onto the resin. The matrix was packed into a column $(1.2 \times 30$ $\left.\mathrm{cm}, \mathrm{SciLab}^{\circledR}, \mathrm{USA}\right)$ and washed twice with washing buffer ( $40 \%$ ethanol). The active solution was recovered using elution buffer (70\% 2-propanol and $10 \mathrm{mM}$ acetic acid, $\mathrm{pH} 2.0$ ).

The Sep-Pak $\mathrm{C}_{18}$ cartridge column (Millipore, USA) was initially rinsed and equilibrated using 100\% acetonitrile supplemented with $0.1 \%$ trifluoroacetic acid. The equilibrated column was washed using distilled water containing $0.1 \%$ trifluoroacetic acid. The active solution was loaded onto a $\mathrm{C}_{18}$ cartridge column and eluted as an antibacterial fraction with acetonitrile containing $0.1 \%$ trifluoroacetic acid. Then, it was dried using a vacuum concentrator (Savant spd1010, Thermo Scientific, USA) to remove the solvent and finally dissolved in $50 \mathrm{mM}$ Tris-Cl buffer ( $\mathrm{pH} 7.0$ ) for determination of the molecular weight of the active substance. The activity and protein concentration of the purified anti-listerial substance were determined using the serial twofold dilution method and Bradford protein assay (Bradford, 1976), respectively, and antimicrobial activity was assessed using the agar well diffusion assay described above (Table 2).

\section{Characterization of the anti-listerial substance}

\section{Enzyme sensitivity}

The substance purified from the SD501 culture supernatant was treated with the following enzymes, each at a final concentration of $5 \mathrm{mg} / \mathrm{mL}$ : $\alpha$-amylase, $\alpha$-chymotrypsin, lipase, proteinase $\mathrm{K}$, pepsin and trypsin (all from Sigma). All preparations were incubated for $2 \mathrm{~h}$ at the appropriate temperatures, and residual antimicrobial activity against $L$. monocytogenes ATCC 19114 was examined using the agar well diffusion assay.

\section{Effect of pH}

The effect of $\mathrm{pH}$ on the anti-listerial substance was evaluated by adjusting the purified substance to $\mathrm{pH}$ 1.0-10.0 (at increments of one $\mathrm{pH}$ unit) with sterile $3 \mathrm{~N} \mathrm{NaOH}$ or $3 \mathrm{~N} \mathrm{HCl}$. After a $2 \mathrm{~h}$ incubation at $37^{\circ} \mathrm{C}$, the samples were re-adjusted to $\mathrm{pH} 7.0$ with $3 \mathrm{~N} \mathrm{NaOH}$ or $3 \mathrm{~N} \mathrm{HCl}$ and evaluated for anti-listerial activity using the agar well diffusion assay.

\section{Heat stability}

To determine the effect of temperature on the anti-listerial substance, the substance was subjected to $4^{\circ} \mathrm{C}, 25^{\circ} \mathrm{C}, 37^{\circ} \mathrm{C}$,

Table 2. Purification of the SD501 bacteriocin by ammonium sulfate (AS) precipitation, Amberlite XAD-16N and hydrophobic $\mathrm{C}_{18}$ column

\begin{tabular}{lcccccc}
\hline Fraction & $\begin{array}{c}\text { Volume } \\
(\mathrm{mL})\end{array}$ & $\begin{array}{c}\text { Total protein } \\
(\mathrm{mg})\end{array}$ & $\begin{array}{c}\text { Total activity } \\
(\mathrm{AU})\end{array}$ & $\begin{array}{c}\text { Specific activity } \\
(\mathrm{AU} / \mathrm{mg})\end{array}$ & $\begin{array}{c}\text { Purification } \\
(\text { fold })\end{array}$ & $\begin{array}{c}\text { Yield } \\
(\%)\end{array}$ \\
Culture supernatant & 4,000 & 480 & $2,800,000$ & 5,833 & 1 & 100 \\
AS precipitation & 8 & 84.8 & 890,400 & 10,500 & 32 \\
Amberlite XAD-16N & 2 & 12.6 & 360,120 & 28,581 & 1.8 & 4.9 \\
C18 column & 1 & 0.24 & 11,339 & 47,247 & 8.1 & 0.4 \\
\hline
\end{tabular}

AU, activity units. 
$50^{\circ} \mathrm{C}, 60^{\circ} \mathrm{C}, 80^{\circ} \mathrm{C}, 100^{\circ} \mathrm{C}$, and $121^{\circ} \mathrm{C}$. Residual anti-listerial activity was tested after a 15 min incubation at these temperatures using the agar well diffusion assay.

\section{Determination of the molecular weight of the anti-listerial substance}

The molecular weight of the partially purified anti-listerial substance was determined using a tricine sodium dodecyl sulfatepolyacrylamide gel electrophoresis (SDS-PAGE) system, as described by Schägger and von Jagow (1987), using 4\% acrylamide for the stacking gel, $10 \%$ acrylamide for the spacer gel and $16.5 \%$ acrylamide for the separating gel. The sample was mixed with sample buffer without SDS and boiled at $100^{\circ} \mathrm{C}$ for $10 \mathrm{~min}$. Electrophoresis was performed using vertical gels (1.5 mm thickness) in an electrophoresis chamber (PowerPac 300, Bio-Rad, USA) at $30 \mathrm{~V}$ for $12 \mathrm{~h}$. After electrophoresis, one gel was placed in staining buffer (0.025\% (w/v) Coomassie Brilliant Blue G-250 (Bio-Rad, USA), 10\% (v/v) acetic acid, 45\% $(\mathrm{v} / \mathrm{v})$ distilled water and $45 \%(\mathrm{v} / \mathrm{v})$ methanol for $1 \mathrm{~h}$, then destained with destaining buffer (10\% (v/v) acetic acid, $45 \%(\mathrm{v} / \mathrm{v})$ distilled water and $45 \%(\mathrm{v} / \mathrm{v})$ methanol for $24 \mathrm{~h}$. The other gel was fixed using destaining buffer, and then washed three times in distilled water for $3 \mathrm{~h}$ and then overlaid with $0.75 \%(\mathrm{w} / \mathrm{v})$ soft agar inoculated with L. monocytogenes ATCC $19114(0.1 \%$, $\mathrm{v} / \mathrm{v})$. The plate was incubated at $25^{\circ} \mathrm{C}$ overnight, and the gel was examined for an inhibition zone.

\section{Results and Discussion}

\section{Isolation and identification of a strain showing anti-listerial activity}

Presumptive LAB grown on MRS agar plates were selected, and their neutralized cell-free supernatants were evaluated for antimicrobial activity against L. monocytogenes ATCC 19114 using the agar well diffusion assay. Of 140 strains tested in this study, strain SD501 showed strong anti-listerial activity and was selected for further investigation. The 16S rDNA sequence of strain SD501 showed the most similarity (100\%) to that of Leuc. lactis CAU7596 (data not shown). Therefore, this strain was confirmed to belong to the species Leuc. lactis and was designated Leuc. lactis SD501. The sequence determined in this study has been deposited in the NCBI database under accession number MF108705.1. To date, anti-listerial substances from Leuc. lactis strains have been reported by Cholakov et al. (2017) and Yehia et al. (2017). However, their studies lack data on the characteristics of the anti-listerial substances.

\section{Production of an anti-listerial substance}

The relationship between the cell growth stage and anti-listerial activity of Leuc. lactis SD501 was determined (Fig. 1). Anti-listerial activity was first detected at $3 \mathrm{~h}$, when the culture was in the early logarithmic phase. Anti-listerial activity reached a maximum $(735 \mathrm{AU} / \mathrm{mL})$ during the early stationary phase $(9 \mathrm{~h})$ and then decreased gradually, as previously reported for most bacteriocins from LAB (Arakawa et al., 2016; Chen et al., 2018; Makhloufi et al., 2013; Wulijideligen et al., 2012; Zamfir et al., 2016). Decreased antimicrobial activity after prolonged incubation of the bacteria could be attributed to processes such as proteolytic degradation by extracellular proteases, re-adsorption by the surface of the producing cell, or protein aggregation (Papagianni and Papamichae, 2011).

\section{Antimicrobial spectrum}

The antimicrobial spectrum of the purified substance from Leuc. lactis SD501 is shown in Table 1. The agar well diffusion assay showed that the antimicrobial substance from Leuc. lactis SD501 exhibited a narrow antimicrobial spectrum. It was 


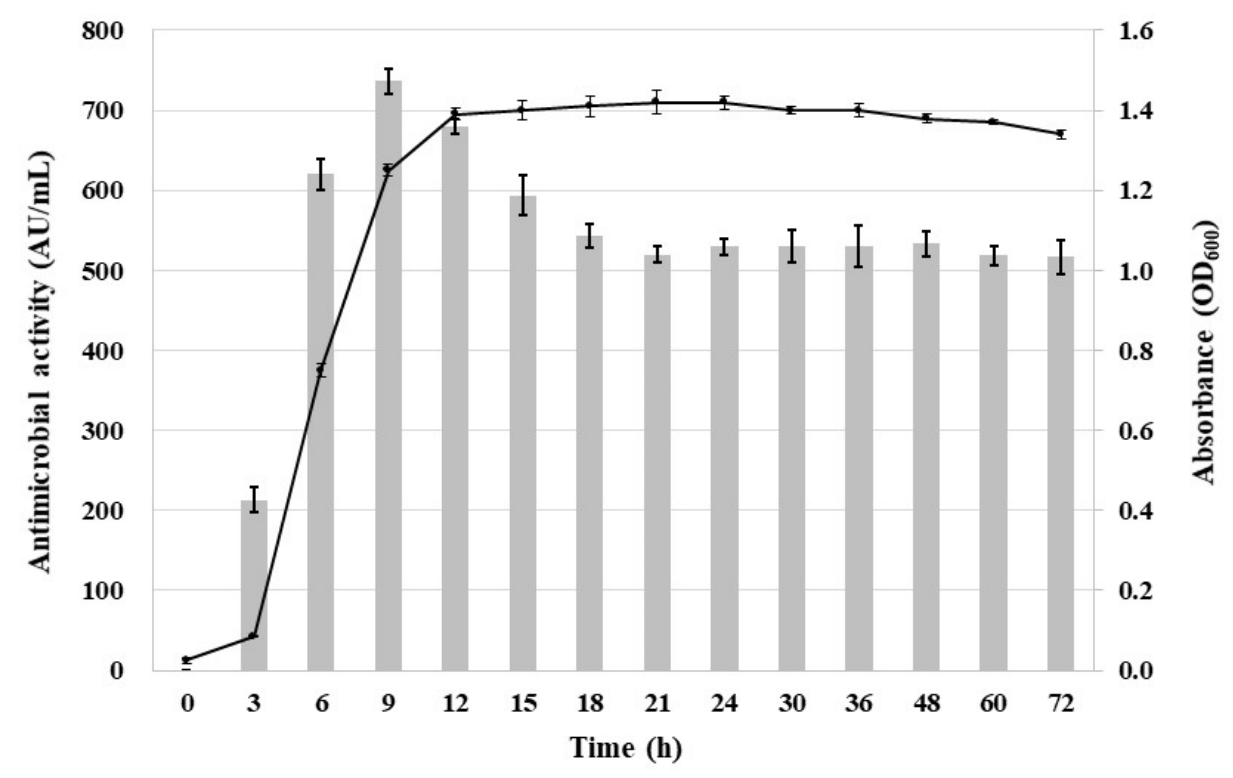

Fig. 1. Antimicrobial activity $(\mathrm{AU} / \mathrm{mL})$ during the growth of Leuconostoc lactis SD501. Symbols: circles, cell density $\left(\mathrm{OD}_{600}\right)$. $A U$, arbitrary unit.

particularly potent against L. monocytogenes and also inhibited Enterococcus faecalis. On the other hand, it was not active against any other Gram-positive or Gram-negative bacteria evaluated.

\section{Characterization of the anti-listerial substance}

The effects of physicochemical treatments on the stability of the purified anti-listerial substance from Leuc. lactis SD501 are summarized in Table 3. The anti-listerial substance was sensitive to several proteolytic enzymes (proteinase $\mathrm{K}$ and achymotrypsin), confirming its proteinaceous nature. However, it was resistant to catalase and amylase, indicating that carbohydrates are not bound to the substance, and its antimicrobial effect was not derived from hydrogen peroxide.

The effect of $\mathrm{pH}$ on the anti-listerial substance was assessed after adjusting the $\mathrm{pH}$ from 1.0 to 10.0 for $2 \mathrm{~h}$ and then readjusted to $\mathrm{pH}$ 7.0. The antimicrobial activity remained stable at $\mathrm{pH}$ values ranging from 1 to 10 . Its activity was even increased after adjusting to acidic conditions before neutralization. Some bacteriocins, such as nisin, showed highest activity in acidic conditions. Tuncer and Ozden (2010) reported that antimicrobial activity of nisin-like bacteriocin from Lac. lactis was highest below $\mathrm{pH}$ 4.0. The influence of $\mathrm{pH}$ on the antimicrobial activity of bacteriocin could be due to changes in the conformation/oligomerization of the bacteriocin peptide as well as to changes in the surface charge of the target microorganisms (Abriouel et al., 2001). In other words, some bacteriocins form monomeric structure than oligomeric one at low $\mathrm{pH}$ and show higher antimicrobial activity (Alvarez-Cisneros et al., 2010).

Furthermore, the inhibitory activity was strongly resistant to high temperatures and was retained even after incubation for $15 \mathrm{~min}$ at $121^{\circ} \mathrm{C}$. Similar results were reported for mesentericin ST99 from Leuc. mesenteroides (Todorov and Dicks, 2004) and leucocin A from Leuc. mesenteroides (Balay et al., 2017).

Bacteriocins that are active against Listeria with a wide $\mathrm{pH}$ stability and good thermostability similar to those of SD501, such as leucocin (Balay et al., 2017), acidocin (Kanatani et al., 1995), mesentericin (Todorov and Dicks, 2004), pediocin (Porto et al., 2017) and sakacin (Simon et al., 2002), are classified as Class II bacteriocins among four classes of bacteriocins (Alvarez-Sieiro, 2016; Balciunasa et al., 2013). 
Table 3. Effects of $\mathrm{pH}$, temperature and various enzymes on the anti-listerial substance obtained from Leuconostoc lactis SD501

\begin{tabular}{|c|c|}
\hline Treatment & Residual activity ${ }^{1)}$ \\
\hline None (Control) & + \\
\hline \multicolumn{2}{|l|}{ Enzyme $^{2)}$} \\
\hline$\alpha$-Amylase & + \\
\hline Lipase & + \\
\hline Proteinase-K & - \\
\hline Trypsin & + \\
\hline$\alpha$-Chymotrypsin & - \\
\hline Pepsin & + \\
\hline \multicolumn{2}{|l|}{ Heat: } \\
\hline $25^{\circ} \mathrm{C}$ & + \\
\hline $50^{\circ} \mathrm{C}$ & + \\
\hline $60^{\circ} \mathrm{C}$ & + \\
\hline $80^{\circ} \mathrm{C}$ & + \\
\hline $100^{\circ} \mathrm{C}$ & + \\
\hline $121^{\circ} \mathrm{C}$ & + \\
\hline \multicolumn{2}{|l|}{ pH: } \\
\hline 2 & ++ \\
\hline 3 & + \\
\hline 4 & + \\
\hline 5 & + \\
\hline 6 & + \\
\hline 7 & + \\
\hline 8 & + \\
\hline 9 & + \\
\hline 10 & + \\
\hline
\end{tabular}

1) Residual activity compared with antibacterial activity prior to treatment. Activity is expressed based on the diameter of the inhibition zone around the well. Degrees of inhibition around the well: -, no inhibition; +, up to $20 \mathrm{~mm}$; ++, up to $25 \mathrm{~mm}$.

2) The enzyme concentration used was $5 \mathrm{mg} / \mathrm{mL}$.

\section{Determination of the molecular weight of the anti-listerial substance}

In Tris-tricine SDS-PAGE analysis, the active fraction of partially purified Leuc. lactis SD501 showed a single band corresponding to a molecular mass of approximately $7 \mathrm{kDa}$ on a gel stained with Coomassie Brilliant Blue (Fig. 2A). In postelectrophoretic detection analysis, the inhibitory activity of that band was confirmed by overlaying the bacteriocin-containing gel with $0.75 \%(\mathrm{w} / \mathrm{w})$ soft agar containing the indicator strain L. monocytogenes ATCC 19114 (Fig. 2B).

Overall, a small molecular size $(<10 \mathrm{kDa})$, strong anti-listerial activity, wide $\mathrm{pH}$ stability and good thermostability are common characteristics of class IIa bacteriocins. Therefore, the anti-listerial bacteriocin from Leuc. lactis SD501 may be classified as a Class IIa bacteriocin, based on the accepted bacteriocin classification system (Alvarez-Sieiro, 2016; Balciunasa et al., 2013). The amino acid sequence, mode of action and genes involved in biosynthesis of SD501 bacteriocin need to be elucidated by future research.

\section{Conclusion}

Anti-listerial bacteriocin was obtained from Leuc. lactis SD501 isolated from kimchi, to our knowledge, which is the first characterized bacteriocin from the species Leuc. lactis. This bacteriocin with high thermostability and activity in a wide range 

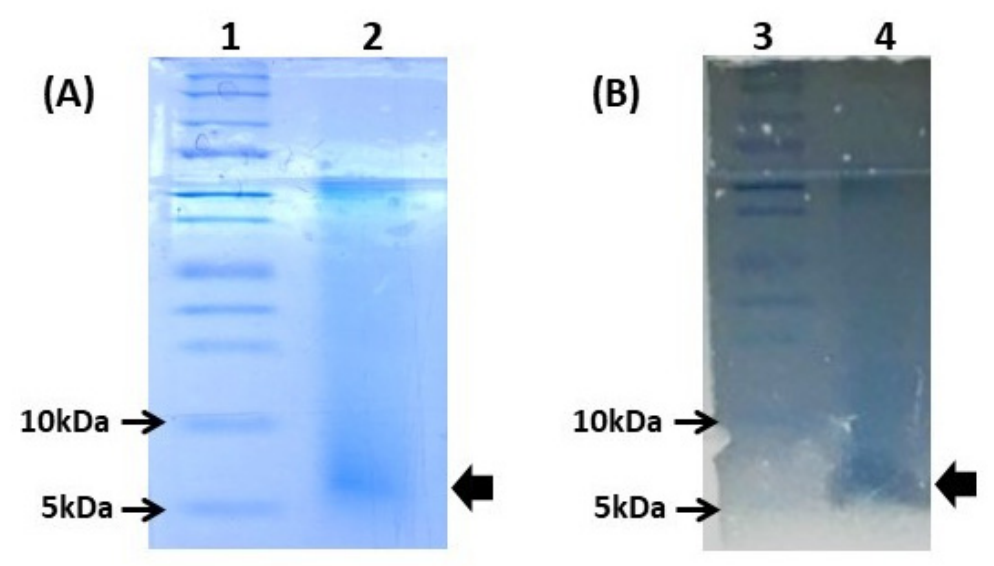

Fig. 2. Molecular weight estimation of the Leuconostoc lactis SD501 bacteriocin. (A) Tricine SDS-PAGE gel stained with Coomassie Brilliant Blue G250 for protein detection. (B) Tricine gel overlaid with soft agar containing Listeria monocytogenes ATCC 19114: lanes 1 and 3, Precision Plus Protein ${ }^{\mathrm{TM}}$ Dual Xtra Prestained Protein Standards marker; lanes 2 and 4, purified bacteriocin from Leuc. lactis SD501.

of $\mathrm{pH}$ could be a promising biopreservative for the control of L. monocytogenes in foods, including dairy and meat products.

\section{Acknowledgements}

The present research was conducted by the research fund of Dankook University in 2018.

\section{References}

Abriouel H, Valdivia E, Gálvez A, Maqueda M. 2001. Influence of physico-chemical factors on the oligomerization and biological activity of bacteriocin AS-48. Curr Microbiol 42:89-95.

Alvarez-Cisneros YM, Fernández FJ, Wacher-Rodarte C, Aguilar MB, Sáinz Espuñes Tdel R, Ponce-Alquicira E. 2010. Biochemical characterization of a bacteriocin-like inhibitory substance produced by Enterococcus faecium MXVK29, isolated from Mexican traditional sausage. J Sci Food Agric 90:2475-2481.

Alvarez-Sieiro P, Montalbán-López M, Mu D, Kuipers OP. 2016. Bacteriocins of lactic acid bacteria: Extending the family. Appl Microbiol Biotechnol 100:2939-2951.

Arakawa K, Yoshida S, Aikawa H, Hano C, Bolormaa T, Burenjargal S, Miyamoto T. 2016. Production of a bacteriocin-like inhibitory substance by Leuconostoc mesenteroides subsp. dextranicum 213M0 isolated from Mongolian fermented mare milk, airag. Anim Sci J 87:449-456.

Balay DR, Dangeti RV, Kaur K, McMullen LM. 2017. Purification of leucocin A for use on wieners to inhibit Listeria monocytogenes in the presence of spoilage organisms. Int J Food Microbiol 255:25-31.

Balciunasa EM, Martineza FAC, Todorovb SD, de Melo Francob BDG, de Souza Oliveira ACRP. 2013. Novel biotechnological applications of bacteriocins: A review. Food Control 32:134-142.

Barmpalia IM, Koutsoumanis KP, Geornaras I, Belk KE, Scanga JA, Kendall PA, Smith GC, Sofos JN. 2005. Effect of antimicrobials as ingredients of pork bologna for Listeria monocytogenes control during storage at 4 or $10^{\circ} \mathrm{C}$. Food Microbiol 22:205-211.

Bradford MM. 1976. A rapid and sensitive method for the quantitation of microgram quantities of protein utilizing the 
principle of protein-dye binding. Anal Biochem 72:248-254.

Byelashov OA, Kendall PA, Belk KE, Scanga JA, Sofos JN. 2008. Control of Listeria monocytogenes on vacuum-packaged frankfurters sprayed with lactic acid alone or in combination with sodium lauryl sulfate. J Food Prot 71:728-734.

Chen YS, Wu HC, Kuo CY, Chen YW, Ho S, Yanagida F. 2018. Leucocin C-607, a novel bacteriocin from the multiplebacteriocin-producing Leuconostoc pseudomesenteroides 607 isolated from persimmon. Probiotics Antimicrob Proteins 10:148-156.

Chumchalova J, Josephsen J, Plockova M. 1995. Characterization of acidocin CH5, a saccharolytic sensitive bacteriocin of Lactobacillus acidophilus CH5. Chem Mikrobiol Techonl Lebensm 17:145-150.

Cholakov R, Tumbarski Y, Yanakieva V, Dobrev I, Salim Y, Denkova Z. 2017. Antimicrobial activity of Leuconostoc lactis strain BT17, isolated from a spontaneously fermented cereal beverage (Boza). J Microbiol Biotechnol Food Sci 7:47-49.

Felix JV, Papathanasopoulos MA, Smith AA, von Holy A, Hastings JW. 1994. Characterization of leucocin B-Ta11a: A bacteriocin from Leuconostoc carnosum Ta11a isolated from meat. Curr Microbiol 29:207-212.

Feng G, Guron GK, Churey JJ, Worobo RW. 2009. Characterization of mundticin L, a class IIa anti-Listeria bacteriocin from Enterococcus mundtii CUGF08. Appl Environ Microbiol 75:5708-5713.

Ghalfi H, Kouakou P, Duroy M, Daoudi A, Benkerroum N, Thonart P. 2006. Antilisterial bacteriocin-producing strain of Lactobacillus curvatus CWBI-B28 as a preservative culture in bacon meat and influence of fat and nitrites on bacteriocins production and activity. Food Sci Technol Int 12:325-333.

Halimi B, Dortu C, Arguelles-Arias A, Thonart P, Joris B, Fickers P. 2010. Antilisterial activity on poultry meat of amylolysin, a bacteriocin from Bacillus amyloliquefaciens GA1. Probiotics Antimicrob Proteins 2:120-125.

Han KS, Kim Y, Kim SH, Oh S. 2007. Characterization and purification of acidocin 1B, a bacteriocin produced by Lactobacillus acidophilus GP1B. J Microbiol Biotechnol 17:774-783.

Heng NC, Burtenshaw GA, Jack RW, Tagg JR. 2007. Ubericin A, a class IIa bacteriocin produced by Streptococcus uberis. Appl Environ Microbiol 73:7763-7766.

Kanatani K, Oshimura M, Sano K. 1995. Isolation and characterization of acidocin A and cloning of the bacteriocin gene from Lactobacillus acidophilus. Appl Environ Microbiol 61:1061-1067.

Kim S, Lee H, Lee S, Yoon Y, Choi KH. 2015. Antimicrobial action of oleanolic acid on Listeria monocytogenes, Enterococcus faecium, and Enterococcus faecalis. PLoS One 10: e0118800.

Koch J, Dworak R, Prager R, Becker B, Brockmann S, Wicke A, Wichmann-Schauer H, Hof H, Werber D, Stark K. 2010. Large listeriosis outbreak linked to cheese made from pasteurized milk, Germany, 2006-2007. Foodborne Pathog Dis 7:1581-1584.

Larsen AG, Vogensen FK, Josephsen J. 1993. Antimicrobial activity of lactic acid bacteria isolated from sour doughs: Purification and characterization of bavaricin A, a bacteriocin produced by Lactobacillus bavaricus MI401. J Appl Bacteriol 75:113-122.

Latorre AA, Van Kessel JS, Karns JS, Zurakowski MJ, Pradhan AK, Boor KJ, Jayarao BM, Houser BA, Daugherty CS, Schukken YH. 2010. Biofilm in milking equipment on a dairy farm as a potential source of bulk tank milk contamination with Listeria monocytogenes. J Dairy Sci 93:2792-2802.

Lecompte JY, Kondjoyan A, Sarter S, Portanguen S, Collignan A. 2008. Effects of steam and lactic acid treatments on inactivation of Listeria innocua surface-inoculated on chicken skins. Int J Food Microbiol 127:155-161.

Lee J, Gwak E, Lee H, Ha J, Lee S, Kim S, Oh MH, Park BY, Choi KH, Yoon Y. 2017. Effects of low $\mathrm{NaNO}_{2}$ and $\mathrm{NaCl}$ 
concentrations on Listeria monocytogenes growth in emulsion-type sausage. Asian-Australas J Anim Sci 30:432-438.

Lim KB, Balolong MP, Kim SH, Oh JK, Lee JY, Kang DK. 2016. Isolation and characterization of a broad spectrum bacteriocin from Bacillus amyloliquefaciens RX7. Biomed Res Int 2016:8521476.

Low JC, Donachie W. 1997. A review of Listeria monocytogenes and listeriosis. Vet J 153:9-29.

Makhloufi KM, Carré-Mlouka A, Peduzzi J, Lombard C, van Reenen CA, Dicks LM, Rebuffat S. 2013. Characterization of leucocin B-KM432Bz from Leuconostoc pseudomesenteroides isolated from boza, and comparison of its efficiency to pediocin PA-1. PLoS One 8:e70484.

Marques JL, Funck GD, Dannenberg GDS, Cruxen CEDS, Halal SLME, Dias ARG, Fiorentini ÂM, Silva WPD. 2017. Bacteriocin-like substances of Lactobacillus curvatus P99: Characterization and application in biodegradable films for control of Listeria monocytogenes in cheese. Food Microbiol 63:159-163.

Massa S, Cesaroni D, Poda G, Trovatelli LD. 1990. The incidence of Listeria spp. in soft cheeses, butter and raw milk in the province of Bologna. J Appl Bacteriol 68:153-156.

Mathur H, Field D, Rea MC, Cotter PD, Hill C, Ross RP. 2017. Bacteriocin-antimicrobial synergy: A medical and food perspective. Front Microbiol 8:1205.

Meyer-Broseta S, Diot A, Bastian S, Rivière J, Cerf O. 2003. Estimation of low bacterial concentration: Listeria monocytogenes in raw milk. Int J Food Microbiol 80:1-15.

Pak SI, Spahr U, Jemmi T, Salman MD. 2002. Risk factors for L. monocytogenes contamination of dairy products in Switzerland, 1990-1999. Prev Vet Med 53:55-65.

Papagianni M, Papamichae EM. 2011. Purification, amino acid sequence and characterization of the class IIa bacteriocin weissellin A, produced by Weissella paramesenteroides DX. Bioresour Technol 102:6730-6734.

Pavlova SI, Kilic AO, Kilic SS, So JS, Nader-Macias ME, Simoes JA, Tao L. 2002. Genetic diversity of vaginal lactobacilli from women in different countries based on 16S rRNA gene sequences. J Appl Microbiol 92:451-459.

Pintado CMBS, Oliveirab A, Pampulhab ME, Ferreira MASS. 2005. Prevalence and characterization of Listeria monocytogenes isolated from soft cheese. Food Microbiol 22: 79-85.

Porto MC, Kuniyoshi TM, Azevedo PO, Vitolo M, Oliveira RP. 2017. Pediococcus spp.: An important genus of lactic acid bacteria and pediocin producers. Biotechnol Adv 35:361-374.

Ryser ET, Arimi SM, Bunduki MM, Donnelly CW. 1996. Recovery of different Listeria ribotypes from naturally contaminated, raw refrigerated meat and poultry products with two primary enrichment media. Appl Environ Microbiol 62:1781-1787.

Saravanan C, Shetty PK. 2016. Isolation and characterization of exopolysaccharide from Leuconostoc lactis KC117496 isolated from idli batter. Int J Biol Macromol 90:100-106.

Schägger H, von Jagow G. 1987. Tricine-sodium dodecyl sulfate-polyacrylamide gel electrophoresis for the separation of proteins in the range from 1 to $100 \mathrm{kDa}$. Anal Biochem 166:368-379.

Schuppler M, Loessner MJ. 2010. The opportunistic pathogen Listeria monocytogenes: Pathogenicity and interaction with the mucosal immune system. Int J Inflam 2010:704321.

Seo SH, Jung M, Kim WJ. 2014. Antilisterial and amylase-sensitive bacteriocin producing Enterococcus faecium SH01 from Mukeunji, a Korean over-ripened Kimchi. Food Sci Biotechnol 23:1177-1184.

Simon L, Fremaux C, Cenatiempo Y, Berjeaud JM. 2002. Sakacin G, a new type of antilisterial bacteriocin. Appl Environ Microbiol 68:6416-6420. 
Todorov SD, Dicks LM. 2004. Characterization of mesentericin ST99, a bacteriocin produced by Leuconostoc mesenteroides subsp. dextranicum ST99 isolated from boza. J Ind Microbiol Biotechnol 31:323-329.

Tuncer Y, Ozden B. 2010. Partial biochemical characterization of nisin-like bacteriocin produced by Lactococcus lactis subsp. lactis YBD11 isolated from boza, a traditional fermented Turkish beverage. Rom Biotechnol Lett 15:4940-4948.

Wulijideligen, Asahina T, Hara K, Arakawa K, Nakano H, Miyamoto T. 2012. Production of bacteriocin by Leuconostoc mesenteroides 406 isolated from Mongolian fermented mare's milk, airag. Anim Sci J 83:704-711.

Xiraphi N, Georgalaki M, Driessche GV, Devreese B, Beeumen JV, Tsakalidou E, Metaxopoulos J, Drosinos EH. 2006. Purification and characterization of curvaticin L442, a bacteriocin produced by Lactobacillus curvatus L442. Antonie Van Leeuwenhoek 89:19-26.

Yehia HM, Ghanem S, Elobeid T, Mosilhey SH, Savvaidis IN. 2017. In vitro characterization of a vancomycin-resistant strain of Leuconostoc lactis isolated from chicken carcasses and its activity against some foodborne pathogens. African J Food Sci 11:337-345.

Yoon Y, Kendall PA, Belk KE, Scanga JA, Smith GC, Sofos JN. 2009. Modeling the growth/no-growth boundaries of postprocessing Listeria monocytogenes contamination on frankfurters and bologna treated with lactic acid. Appl Environ Microbiol 75:353-358.

Zamfir M, Stefan IR, Stancu MM, Grosu-Tudor SS. 2016. Production, mode of action and sequencing of the corresponding gene of a bacteriocin produced by Lactococcus lactis 19.3. Int J Food Sci Technol 51:2164-2170. 